\title{
BALANCING CHEMICAL EQUATIONS USING SANDWICH MAKING COMPUTER SIMULATION GAMES AS A SUPPORTING TEACHING METHOD
}

\author{
Martin Bílek \\ Charles University, Czech Republic \\ E-mail: martin.bilek@pedf.cuni.cz \\ Małgorzata Nodzyńska \\ Pedagogical University, Poland \\ E-mail: malgorzata.nodzynska@gmail.com \\ Wioleta Kopek-Putała \\ University of Hradec Kralove, Czech Republic \\ E-mail: wioleta.kopekputala@uhk.cz \\ Paulina Zimak-Piekarczyk \\ E-mail: p.zimak@ifr-pan.edu.pl
}

Polish Academy of Sciences, \& State High School of Art, Poland

\begin{abstract}
Writing and balancing equations of chemical reactions is one of the Imost difficult elements of chemistry education for students, which is why it was decided to analyse part of the process which is the most difficult. The process itself consists of multiple stages. it is important to highlight that the focus of research was not only on balancing the chemical equations. This stage can be independent of chemical skills and knowledge and is based on combinatorial and mathematical skills.

The aim of the research was to examine whether using computer simulations can help younger children to balance chemical equations before they start to learn chemistry by using the psychological theory of transfer. It was decided first to teach children how to "make sandwiches" using a computer simulation game. When they have mastered in this activity, they can balance chemical equations. If the children learned how many pieces of cheese, ham and bread would be necessary to "make sandwiches" they began to learn how to balance chemical equations. The children were acquainted with the elements of chemical knowledge necessary to understand the simulation, and then they worked independently with it. Tests were carried out to check the acquired level of ability to balancing chemical equations.

The obtained results proved that the balancing of the simple equation of reaction was mastered by over $50 \%$ of the children tested.

It seems, therefore, a good solution that elements of reconciliation of chemical reaction equations should be introduced at an earlier stage of education, for example during maths lessons.

Keywords: balancing chemical equations, computer simulation game, learning transfer, experimental research design.
\end{abstract}


Martin BÍLEK, Małgorzata NODZYŃSKA, Wioleta KOPEK-PUTAŁA, Paulina ZIMAK-PIEKARCZYK. Balancing chemical equations using

sandwich making computer simulation games as a supporting teaching method

\author{
PROBLEMS \\ OF EDUCATION \\ IN THE $21^{\text {st }}$ CENTURY \\ Vol. 76, No. 6, 2018 \\ 780 Introduction
}

The experiences of teachers notice that majority of students have difficulty comprehending chemistry. This dislike for chemistry may lead to a decision to pursue studies that do not include chemistry (or chemistry related subjects) in their curriculum (Rius-Alonso \& Gonzalez Quesada, 2015). It seems that one of the most difficult elements in learning chemistry is writing and balancing equations of chemical reactions. This is due to several reasons:

- The first of these is the number of subsequent elementary activities that the student must perform to correctly write and balance on the chemical reaction equation. As research conducted in our team shows, the number of elementary steps with a typical double replacement reaction is over 40 (Cieśla \& Paśko, 2006; Haduch \& Paśko, 1999; Nodzyńska \& Paśko, 2008, 2010; Paśko \& Jyż-Kuroś, 2008a; $2008 b)$. It is too difficult for many students.

- The second factor hindering students from acquiring the ability to write and balance equations of chemical reaction is the fact that students find it very difficult to make connections between what they observe in the world around them (macroscopic properties) and the sub-microscopic world of particles, atoms and subatomic units. Yet in order to make sense of the macroscopic properties, chemists switch to the sub-microscopic scale where they use explanatory models to try and explain their observations. Balancing of chemical reaction requires students to move freely on three levels:

- of the macro world - the world of observed chemical reactions;

- micro world - the world of chemical individuals and their transformations, which allows us to explain the processes taking place;

- the world of symbolism (and mathematics) allowing to write equations of chemical reactions.

Research (Schurmeier, Shepler, Lautenschlager, \& Atwood, 2011) also explains why the ability to write and balance chemical reactions is so difficult for many students. During 10 years of research, these scholars identified 8 issues that cause students learning problems. Among them are 3 topics, knowledge of which is necessary for students in the process of writing and balancing equations of chemical reactions. These are:

- $\quad$ particulate nature of matter,

- molecular image problems,

- the mole concept.

Therefore, it can be added that the main problem with writing and balancing equations of chemical reactions is the complexity and multistage character of this process.

\title{
Problem of Research
}

The process of writing and balancing equations of chemical reaction is considered difficult and it consists of more than 40 steps, which is why it was decided to 'disassemble' this process into smaller parts and to examine whether it is possible to teach its individual elements separately. The purpose of this action was to check which activities in this process are the most difficult. As the first element, it was decided to examine the process of balancing the already written reaction equations. This process is independent of the students' chemical knowledge and is based on the skills of logical thinking, the foundations of mathematics and combinatorics. In order to ensure that previously acquired knowledge in the field of chemistry had no influence on research (to avoid the negative transfer effect, stimulus generalization and proactive and retroactive inhibition) primary school students were selected for the research, i.e. students who had not yet studied chemistry. Due to the young age of students (9-12 years) 
to learn how to balance the equations of chemical reactions, it was decided to use computer simulations based on the principles of gaming.

The process of balancing equations of chemical reactions should not be difficult for students from the point of view of mathematics and logic (apart from the complexed equations of oxidation and reduction reactions). For example, in maths classes children can be taught to reconcile equations of chemical reactions before they start to learn chemistry. It was decided to examine whether positive educational transfer can be used to teach balancing equations of chemical reaction. So it was decided to check: would the teaching of students "how to make sandwiches" help them how to balance equations of chemical reaction.

\section{Research Focus}

The justification for why the ability to write and balance equations of chemical reactions is so important can be found in the 2015 edition of the Chemistry Education: Best Practices, Opportunities and Trends handbook (Garcia-Martinez, Serrano-Torregrosa, \& Atkins, 2015). The basic of teaching of chemistry in higher and highest level is balancing on chemical reaction. Chemical equations of chemical mass balances are one of the most important issues. Chemical reaction is the process that one of more substances is converting into a new group of compounds. Equalization is required to react, because in chemical reaction atoms are neither re-created what nor destroyed. Similarly Bergquist and Heikkinen (1990, p. 1000) wrote: "Yet equilibrium is fundamental to student understanding of other chemical topic such as acid and base behaviour, oxidation - reduction reactions, solubility. Master of equilibrium facilitates the mastery of these other chemical concepts."

Agarwal (2004) draws attention to the importance of the ability to write and balance equations of chemical reactions in the process of learning chemistry but also writes about the difficulties students experience when writing and balancing equations of chemical reactions. Particular attention is paid to the "mathematical" cause of these difficulties: The teacher probably finds that some learners are almost incapable of writing correct equations. Increasing familiarity with symbols, formulas and equations makes it necessary to warn pupils that merely to be able to balance equations correctly is not learning Chemistry. Equations must be used as tools, and it must be understood that each symbol represents a definite weight of an element, and that the volumes of gases reacting and produced in an equation are clearly conveyed by their coefficients. It is advisable for the learner to work out a number of suitable arithmetical problems. At first the arithmetical operations involved should be as simple as possible. At every stage the problems should be connected with the pupil's own work and whenever possible with everyday problems. Indeed the solution of suitable problems increases the pupil's knowledge of Chemistry, and makes him realize the advantages of teaming the use of equations.

Although, as shown above, the ability to write and balance equations of chemical reactions is necessary in the process of learning chemistry, many students have problems with this issue, as shown by numerous publications on the subject. E.g. Chandrasegaran, Treagust, Waldrip, and Chandrasegaran (2009) described the research - to investigate the understanding of the limiting reagent concept and the strategies used by students when solving four reaction stoichiometry problems. Students' written problem-solving strategies were studied using the think-aloud protocol during problem-solving, and retrospective verbalisations after each activity. Kern, Wood, Roehrig, and Nyachwaya (2010) made descriptive analysis of U.S. high schools students' particulate representations of a chemical reaction, specifically, the combustion of methane. Naah and Sanger (2012) identify student misconceptions and difficulties in writing symbolic-level balanced equations for dissolving ionic compounds in water. Cokadar and Hulusi (2013) described the difficulties of Turkish students writing chemical formulas of reaction products and also Marias (2014) described the difficulties of students from South Africa with an 
Martin BÍLEK, Małgorzata NODZYŃSKA, Wioleta KOPEK-PUTAŁA, Paulina ZIMAK-PIEKARCZYK. Balancing chemical equations using sandwich making computer simulation games as a supporting teaching method

PROBLEMS

OF EDUCATION

IN THE $21^{\text {st }}$ CENTURY Vol. 76, No. 6, 2018

782

understanding of the molecular level of chemical equations. The amount and popularity of video tutorials showing students how to write and balance equations of chemical reactions contained, for example in Khan Academy, or on the YouTube channel (see Table 1) shows the importance of this problem, too.

Table 1. Numbers and popularity of video tutorials showing students how to write and balance of chemical reactions.

\begin{tabular}{|c|c|c|c|c|}
\hline The title of the video tutorial & Author & $\begin{array}{l}\text { Creation } \\
\text { date }\end{array}$ & $\begin{array}{l}\text { Number of } \\
\text { views }\end{array}$ & Website address \\
\hline Balancing Chemical Equations & Khan Academy & $\begin{array}{l}7 \text { years } \\
\text { ago }\end{array}$ & 2070313 & $\begin{array}{l}\text { https://www.youtube.com/ } \\
\text { watch?v=RnGu3xO2h74 }\end{array}$ \\
\hline Writing lonic Formulas: Introduction & Tyler DeWitt & $\begin{array}{l}4 \text { years } \\
\text { ago }\end{array}$ & 1165741 & $\begin{array}{l}\text { https://www.youtube.com/ } \\
\text { watch?v=URc75hoKGLY }\end{array}$ \\
\hline $\begin{array}{l}\text { Balancing Chemical Equations - } \\
\text { Chemistry Tutorial }\end{array}$ & $\begin{array}{l}\text { The Chemistry } \\
\text { Solution }\end{array}$ & $\begin{array}{l}6 \text { years } \\
\text { ago }\end{array}$ & 1033721 & $\begin{array}{l}\text { https://www.youtube.com/ } \\
\text { watch?v=UGf60kq_ZDI }\end{array}$ \\
\hline $\begin{array}{l}\text { Balancing chemical equations - } \\
\text { Chemical reactions and stoichiom- } \\
\text { etry - Chemistry }\end{array}$ & Khan Academy & $\begin{array}{l}2 \text { years } \\
\text { ago }\end{array}$ & 986758 & $\begin{array}{l}\text { https://www.youtube.com/ } \\
\text { watch?v=TUuABq95BBM }\end{array}$ \\
\hline $\begin{array}{l}\text { Equilibrium: Crash Course Chem- } \\
\text { istry \#28 }\end{array}$ & Crash Course & $\begin{array}{l}3 \text { years } \\
\text { ago }\end{array}$ & 874442 & $\begin{array}{l}\text { https://www.youtube.com/ } \\
\text { watch?v=g5wNg_dKsYY }\end{array}$ \\
\hline
\end{tabular}

Note: (The first 5 video tutorials in terms of number of views - for a total of 72,300 for the query "Balancing

chemical equations" - access date 03/08/2017).

In many publications, as a remedy for the above-described difficulties of students, it can be suggested using, for example visualization of chemical processes at the micro world level (Belford \& Moore, 2016; Ben-Zvi, Eylon, \& Silberstein, 1987; Bilek, Cieśla, Nodzyńska, Paśko, \& Paśko, 2006b; Chang, Quintana, \& Krajcik, 2010; Garnett, Hackling, \& Oliver, 1996; Hsin-Yi Chang \& Shi-Fang Tzeng, 2017; Hsin-Yi Chang, Zhihui H. Zhang, \& ShuYuan Chang, 2014; Jones \& Kelly, 2015; Moore, 2016; Rosenthal \& Sanger, 2012; 2013) or virtual laboratories (Ramirez \& Macias, 2013). Numerous articles also confirmed the impact of computer simulations (Lamanauskas, 2011) on understanding the process of writing and balancing chemical equations (Sarabando, Cravino, \& Soares, 2016), many of which relate to the PhET simulation (Carpenter, Moore, \& Perkins, 2016a; 2016b; Clark \& Chamberlain, 2014; Ganasen \& Shamuganathan, 2017; Lancaster, Moore, Parson, \& Perkins, 2013; Moore, Chamberlain, Parson, \& Perkins, 2014; Padilla et al., 2016).

However, other researchers propose the use of mathematical algorithms to balance chemical reaction equations (Ceyhun \& Karagolge, 2009; Nyachwaya, Warfa, Roehrig, \& Schneider, 2014).

It is widely believed that chemistry as an object requiring abstract thinking, can be taught only at later stages of education (ISCED-2), but research shows that the process of teaching chemistry at earlier stages is possible. For example, in studies conducted by our team in Poland and the Czech Republic (Bilek, Cieśla, Nodzyńska, Paśko, \& Paśko, 2006a) it has been proved that it is possible to teach children from elementary school to build ionic structures of inorganic compounds and in next research (Bilek, Cieśla, Nodzyńska, Paśko, \& Paśko, 2006b) it has been proved that it is possible to teach children from elementary school the understanding of the natural phenomena in the micro-world level using appropriate visualization techniques (ISCED-1). The possibility of teaching children's chemistry at ISCED-0/1 level was also examined (Moskal \& Nodzyńska, 2014). 
Studies conducted by Rius-Alonso and Gonzalez Quezada (2015) also describe the teaching of chemistry through simple chemical experiments of up to 2-3 year-old children (ISCED-0). They teach children chemistry by present in everyday events of life as: the change of colour with a natural colorant; changing the $\mathrm{pH}$, from lemon, to water, to detergent; how to produce large bubbles; why an egg when is dropped in a glass of water sinks but when salt is added it floats.

It can therefore be assumed that the age of children aged 9-12 is a suitable age for carrying out the planned research. In these studies, the following research question was posed: whether the skill of "making sandwiches" will positively affect the ability to balance chemical reactions.

The purpose of this empirical research was to check whether it is possible to introduce the teaching of balancing of chemical reaction equations as a single element in maths lessons in the $3^{\text {rd }}-5^{\text {th }}$ grades of primary school.

In the research, it was decided to use a psychological theory of transfer in learning (Healy \& Wohldmann, 2012; Salaken, Khosravi, Nguyen, \& Nahavandi, 2019). This idea was introduced by Thorndike and Woodworth (1901). They explored, among others, how "improvement in one mental function" could influence at another (similar) mental function. As a result, it was decided to use the PhET simulation "Reactants, Products and Leftovers". In this simulation pupils first, learn a simple activity, known to them from everyday life - they learn to "make sandwiches". And then, after mastering this activity by the children, the transfer of learning was used to teach children to balancing chemical equations. Using the Schunk taxonomy (2004), it can be stated that the studies were based on the following types of transfer:

- far (little overlap between situations, original and transfer settings are dissimilar),

- $\quad$ positive (what is learned in one context enhances learning in a different setting),

- horizontal (knowledge of a previous topic is not essential but helpful to learn a new topic),

- $\quad$ figural (use some aspect of general knowledge to think or learn about a problem).

\section{Research Question}

Main research question was formulated: Can the use of computer simulation game help younger children to balance chemical equations before they start to learn chemistry?

\section{Methodology of Research}

\section{General Background}

The process of learning to balancing chemical equations was supported by the use of visual models in form of computer simulation game. The use of this simulation allowed the student to start from the activities known to the student from everyday life in a macro world (making sandwiches), then go through the world of models (molecules of chemical compounds) to the world of chemical symbolism (mathematical record of the reaction equation).

Experimental design was used for the research. The research tool was a question sheet and children's questioning lasted 45 minutes for each of the groups surveyed.

In the research, a computer simulation was designed and implemented in classes with children of the "University of Children and Parents UP Krakow" and the "Children's University in Wadowice". Mathematical ability to balance equations of reactions was evaluated using pretest and post-tests.

The research was conducted in the academic year 2016/2017 and covered children from 8 to 12 years of age. The children did not learn chemistry yet. 
Martin BÍLEK, Małgorzata NODZYŃSKA, Wioleta KOPEK-PUTAŁA, Paulina ZIMAK-PIEKARCZYK. Balancing chemical equations using sandwich making computer simulation games as a supporting teaching method

OF EDU

IN THE $21^{\text {st }}$ CENTURY Vol. 76, No. 6, 2018

784

\section{Sample Selection}

There are many educational activities for children at the Pedagogical University of Krakow. Two groups of children were selected for the research, who attended the so-called Children's universities. These children have similar interests and are of comparable age.

Children from 8 to 12 years of age from two children's universities took part in the research. Krakow and Wadowice were selected for the research due to the decidedly different character of both cities. Krakow is the second city in Poland with proximately one million inhabitants (Agaciak, 2010; Główny Urząd Statystyczny, 2014) and Wadowice is a small city with 18,516 inhabitants (Urząd Miejski w Wadowicach, n.d.). Group of 91 children from two children's universities participated in the research: 38 children of the "University of Children and Parents of the Pedagogical University of Krakow" and 53 children of the "Children's University in Wadowice". Children from the University of Children and Parents from Krakow were children of the academic staff of the Pedagogical University, while the children from the Wadowice University of Children were children of small entrepreneurs and farmers. Researchers informed participants of the research about the purpose of research in a simple and non-technical language, they informed about potential benefits or risks. The children's parents agreed to carry out research (World Health Organization, 2011).

\section{Experimental Treatment}

The simulation "Reactants, Products and Leftovers" from https://phet.colorado.edu/ was chosen as a tool. A PhET Interactive simulation is a project at the University of Colorado Boulder. It is an open educational resource.-

Using the simulation, children were able to create their own sandwiches (consisting of bread, cheese and ham), they can check how many ingredients are needed to create different number of sandwiches, how many sandwiches will be made with the given amount of ingredients. Then they can compare the process of creating sandwiches to the process of balancing of chemical reaction equations. Work cards and instructions that were given to the children were placed in the appendix.

\section{Instrument and Procedures}

According to the research design (see Figure 1), children participating in the research took a pre-test in order to characterize their knowledge regarding balancing of chemical reaction.

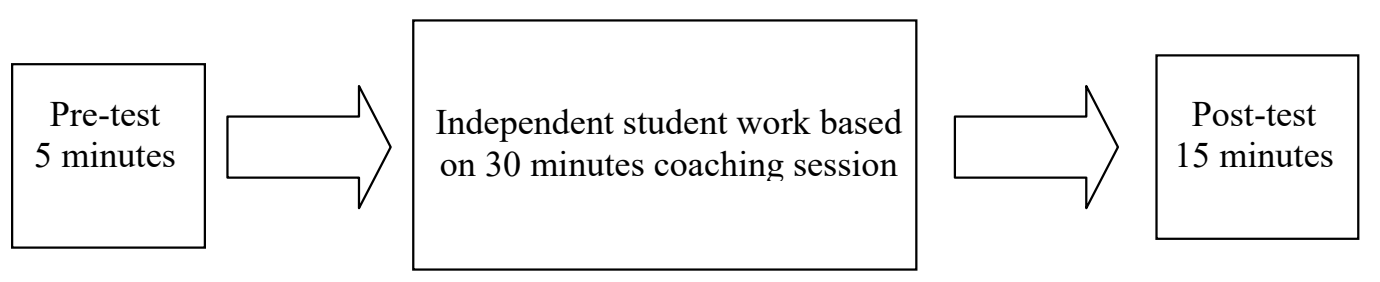

\section{Figure 1. Sequence of activities during classes.}

The research was carried out in the building of the Pedagogical University in Krakow. The activities of children were conducted by the same person. The main hypothesis of the conducted research was:

$\mathrm{H}_{1}$ - The use of computer simulation, which is based on educational transfer, allows children aged 8-12 to understand the ideas of balancing chemical equations. 
Martin BÍLEK, Małgorzata NODZYŃSKA, Wioleta KOPEK-PUTAŁA, Paulina ZIMAK-PIEKARCZYK. Balancing chemical equations using sandwich making computer simulation games as a supporting teaching method

Research hypotheses:

$\mathrm{H}_{\mathrm{a}}$ - The results of children from different social and educational backgrounds are different.

$\mathrm{H}_{\mathrm{b}}$ - The results achieved by children affect interest in the subject.

$\mathrm{H}_{\mathrm{c}}$ - Due to the identical logical and mathematical actions needed to "make sandwiches" as well as balancing equations of chemical reactions, there are no statistically significant differences in children' performance regarding both activities.

\section{Pre-test and Post-test}

The pre-test and post-test contained identical tasks. The test to check the ability to "make sandwiches" using a computer game and to balance the equations of chemical reactions contained four open questions. Two of them concerned the skills of making sandwiches and two of them balancing the equations of reaction. The task of the children was to enter numbers in the empty space in the text.

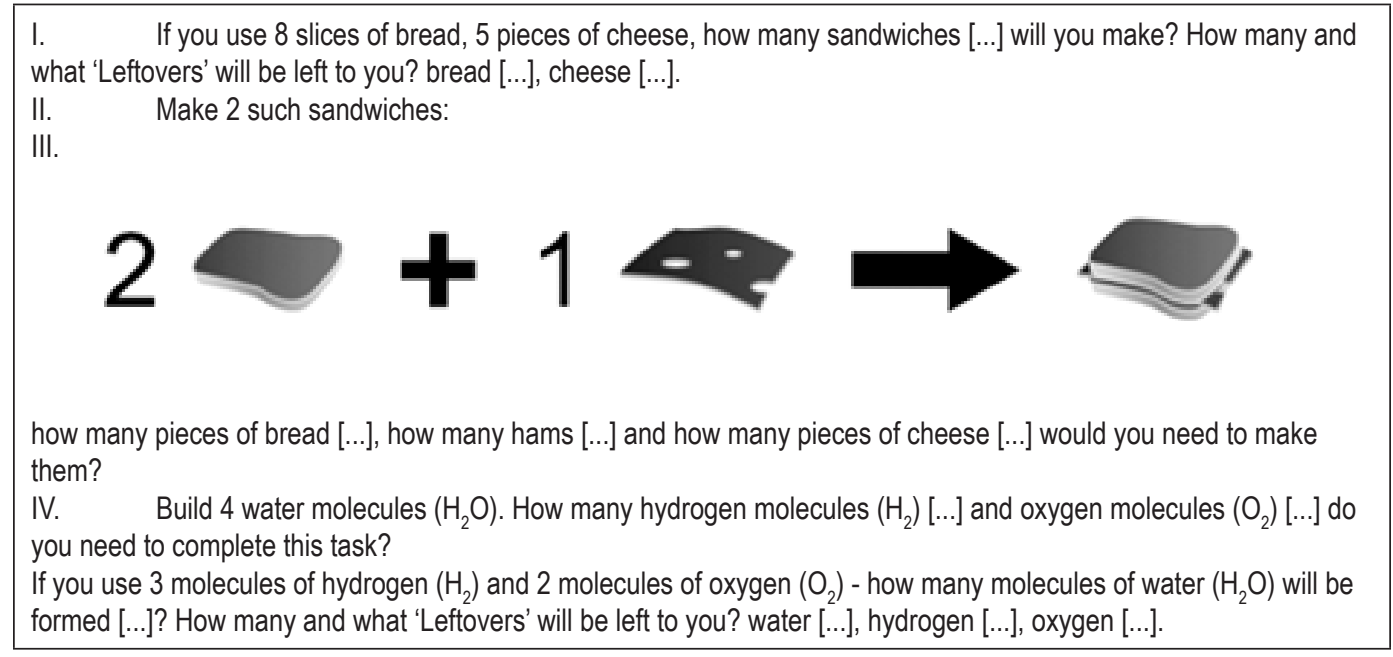

\section{Figure 2. Task used in pre-test and post-test.}

None of the tested children attempted to solve these tasks in the pre-test. Children found that they never encountered such problems and did not know how to solve them. Even encouragement from the teachers conducting these activities did not help. Therefore, it can be assumed that none of the children has ever encountered this problem - therefore, we assume the children' initial knowledge at zero level. This situation did not happen again with the post test. All the respondents decided to solve it. Further data analysis concerns only the increase of knowledge - post-test.

After the post-test, children evaluated the simulation used in the classroom (see Figure 3). 
Martin BÍLEK, Małgorzata NODZYŃSKA, Wioleta KOPEK-PUTAŁA, Paulina ZIMAK-PIEKARCZYK. Balancing chemical equations using sandwich making computer simulation games as a supporting teaching method

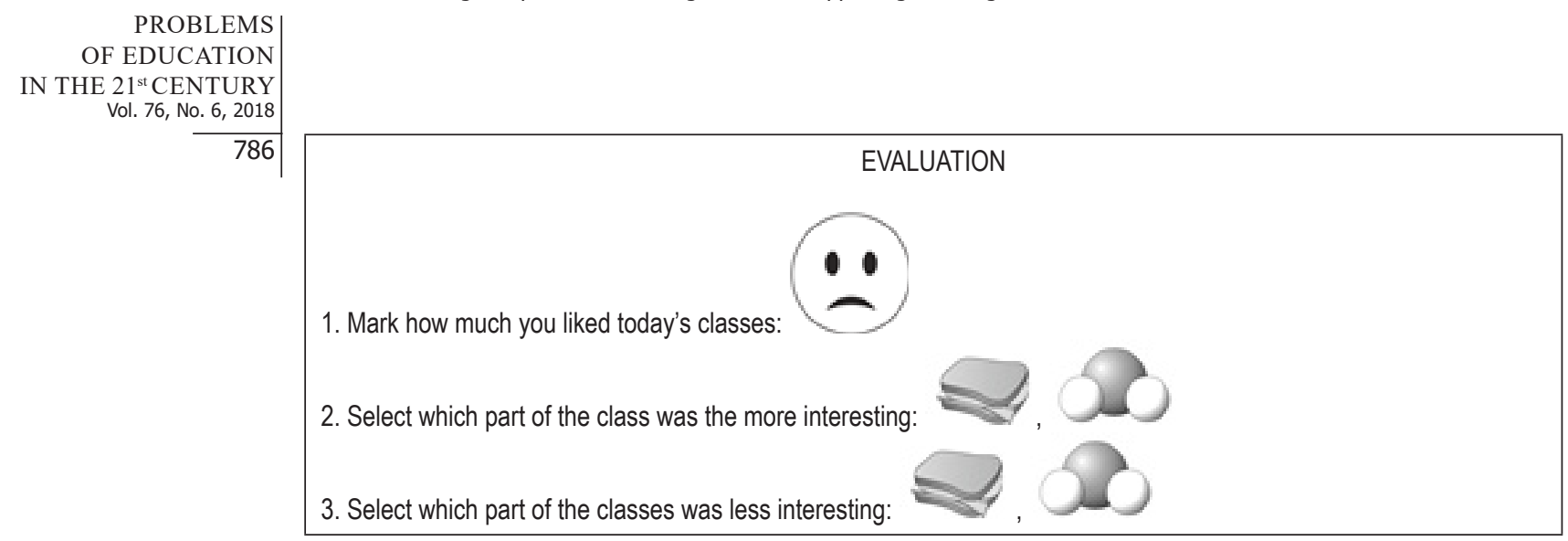

Figure 3. Simple evaluation form of classes for participating children.

Data Analysis

Each answer was evaluated in the following categories: correct - 1 point, incorrect - 0 points. In total, the student could get 12 points:

- $\quad$ six points for two questions about making sandwiches (three points for the first question and three points for the second question),

- $\quad$ six points for two questions regarding the balance of chemical reaction equations (two points for the third question and four points for the fourth question).

The results obtained from the post-test were subjected to statistical analysis. Student's t-test and two-way analysis of variance (ANOVA) were applied. In the analysis of qualitative variables, the $\chi^{2}$ test was used. Null hypotheses were rejected at the level of significance $p \leq .05$. All calculations were performed using Sigma Plot 11.0.

\section{Results of Research}

The first detailed hypothesis was $\mathrm{H}_{\mathrm{a}}$ - the results of children from different social and educational backgrounds are different, but conducted statistical analysis using the ANOVA test did not show differences between the tested samples (i.e. children of the "University of Children and Parents from Krakow" and children of the "Children's University in Wadowice") due to the type of simulation used for sandwiches $(p=.685)$ and for molecules $(p=.941)$. We can therefore state that this hypothesis has been rejected. And that in this test, children' achievements are independent of their place of origin.

Therefore, the results from both trials for individual simulations were combined for further analysis $(n=91)$.

Confirmation or falsification of the next hypothesis $\left(\mathrm{H}_{c}-\right.$ due to the identical logical and mathematical actions needed to "make sandwiches" as well as balancing equations of chemical reactions there will be no major differences in children' performance regarding both activities) requires a comparison of the correctness of the answers to questions about the 'making sandwiches' and 'balancing of chemical reaction equations'. Statistical analysis of children' responses to individual questions (Q1 - Q6 in Figure 4 in Appendix) showed that the percentage of correct answers to questions about 'making sandwiches' was stable regardless of the question and remained within $64.1 \%-74.4 \%$, while the percentage of correct answers regarding 'balancing of chemical reaction equations' depended on the type of question (Q7Q12 in Figure 2 in Appendix). Percentage of correct answers to questions Q7-Q8 and Q9 was stable and remained at a similar level $(64.8 \%-71.4 \%)$ analogically to the questions of making sandwiches. On the other hand, the percentage of correct answers to the next three questions regarding the balance of chemical equations is definitely lower (Q10 - Q12). 


\section{Legend:}

I. If you use 8 slices of bread, 5 pieces of cheese, how many sandwiches [.Q1.] will you make? How many and what 'Leftovers' will be left to you? bread [.Q2.], cheese [.Q3.].

II. Make 2 such sandwiches:

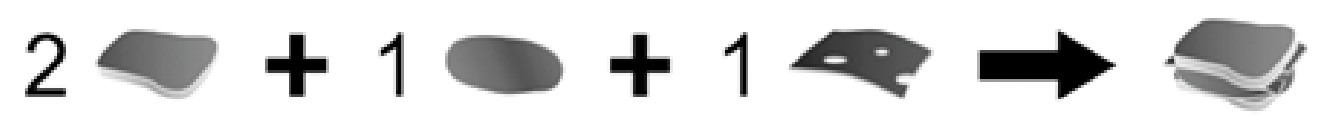

how many pieces of bread [.Q4.], how many hams [.Q5.] and how many pieces of cheese [.Q6.] would you need to make them?

III. Build 4 water molecules $\left(\mathrm{H}_{2} \mathrm{O}\right)$. How many hydrogen molecules $\left(\mathrm{H}_{2}\right)$ [.Q7.] and oxygen molecules $\left(\mathrm{O}_{2}\right)[. \mathrm{Q8}$.] do you need to complete this task?

IV. If you use 3 molecules of hydrogen $\left(\mathrm{H}_{2}\right)$ and 2 molecules of oxygen $\left(\mathrm{O}_{2}\right)$ - how many molecules of water $\left(\mathrm{H}_{2} \mathrm{O}\right)$ will be formed [.Q9.]? How many and what 'Leftovers' will be left to you? water [.Q10.], hydrogen [.Q11.], oxygen [.Q12.].

\section{Figure 4. Percentage of correct answers to questions in the test.}

Summing up this part of the results analysis it can be stated that questions Q1-Q6 regarding 'making sandwiches' and questions Q7-Q9 regarding 'balancing of chemical reactions' have a similar level of correct answers (between 64.1\% - 74.4\%). Questions Q11 and Q12 on "balancing of chemical reactions" were more difficult - the level of correct answers is between $54.9 \%-57.1 \%$. The most difficult question for children (only $26.4 \%$ correct answers) turned out to be question Q10. It concerned the 'Leftovers' water in the reaction of water synthesis.

Taking into account the number of tasks and their scores, the respondents could receive from 0 to 6 points in each part of the post-test. The analysis showed that the maximum results from a given part of the test ( 6 points - all correct answers) were obtained by $44 \%$ of children working on simulation making sandwiches. An analogous result for the balancing of chemical reaction equations was received only by $17 \%$ of the children tested. This is due to the difficulty of question 10 in the section on balancing of chemical reaction equations.

Analysis using the Student's t-test showed statistically significant differences between the simulations used $(t=-2.836, d f=180, p=.005)$. The average point score in the post-test for children working on the "sandwich" simulation was 4.3 points (71\%), for particles 3.4 points (57\%) (Figure 5). 
Martin BÍLEK, Małgorzata NODZYŃSKA, Wioleta KOPEK-PUTAŁA, Paulina ZIMAK-PIEKARCZYK. Balancing chemical equations using sandwich making computer simulation games as a supporting teaching method

PROBLEMS

OF EDUCATION

IN THE $21^{\text {st }}$ CENTURY

Vol. 76, No. 6, 2018

788

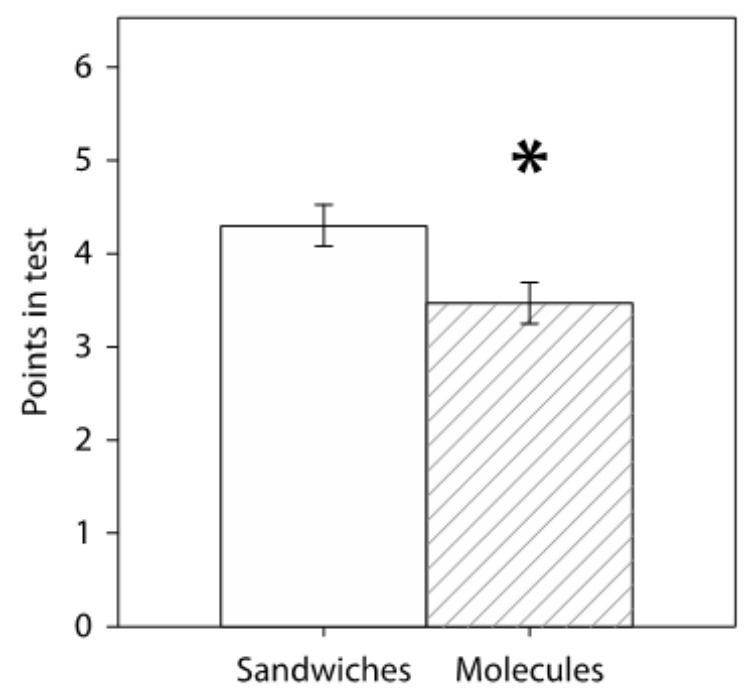

Figure 5. Results obtained by the respondents in particular point ranges after the use of "making sandwich" and "balancing of chemical reaction equations" simulation.

Note: Comparison of effects in the post-test after the simulation of "sandwich" and "molecule". Data represent the mean $\pm \mathrm{SE}(\mathrm{n}=91)$. Asterisks were statistically significant differences according to Student's $\mathrm{t}$ test $\left({ }^{*}\right) p$ $<.05$. "Sandwiches" means "making sandwich" and "molecules" means "balancing equations of chemical reactions".

The results showed that the $\mathrm{H}_{\mathrm{c}}$ hypothesis is not true, despite the need to perform identical logical and mathematical activities, however, "making sandwiches" was more difficult for children than agreeing on the amount of cheese, bread and ham in "making sandwiches". In this situation, it is example of the use transfer of education - High Road / Forward Reaching (which means abstracting situations from a learning context to a potential transfer context).

The third hypothesis concerned the satisfaction on the level of learning new content $\left(\mathrm{H}_{\mathrm{b}}\right.$ - on the results of children, the interest in the subject). This was examined by comparing the evaluation of classes by children (after the post-test, children were asked questions about the evaluation of both types of simulations and of the general evaluation of the classes) with their results.

A total of 73 respondents rated classes using simulations as interesting, 6 children remained neutral, 1 child did not like the course and 11 children did not answer this question (Table 2). The level of satisfaction with the simulation was compared with the number of points obtained from the test. After analysis using the $\chi^{2}$ test, it was found that the general assessment of the course did not affect the obtained test result $\left(\chi^{2}=3.310, d f=2, p=.191\right)$. 
Martin BÍLEK, Małgorzata NODZYŃSKA, Wioleta KOPEK-PUTAŁA, Paulina ZIMAK-PIEKARCZYK. Balancing chemical equations using sandwich making computer simulation games as a supporting teaching method

Table 2. The results of the class evaluation by the children.

The number of children and the score from the post-test

\begin{tabular}{llll}
\cline { 2 - 3 } Class evaluation by the children & $\begin{array}{l}\text { Low } \\
\text { (0-4 points) }\end{array}$ & $\begin{array}{l}\text { Medium } \\
\text { (5-8 points) }\end{array}$ & $\begin{array}{l}\text { High } \\
\text { (9-12) points }\end{array}$ \\
\hline Class evaluation & 12 & 22 & \\
\hline
\end{tabular}

A total of 26 children determined that they liked the simulation of 'making sandwiches' more, and 18 children indicated that they preferred simulation for 'balancing chemical equations'. Many children did not answer this question (19) or provided the answer that both simulations are equally interesting (28) (see Table 3).

Table 3. The results of the class evaluation by the children.

\begin{tabular}{llll}
\hline \multirow{2}{*}{\begin{tabular}{l} 
Class evaluation by the children \\
\cline { 2 - 4 }
\end{tabular}} & $\begin{array}{l}\text { Tow } \\
(0-4 \text { points })\end{array}$ & $\begin{array}{l}\text { Medium } \\
(5-8 \text { points })\end{array}$ & $\begin{array}{l}\text { High } \\
(9-12) \text { points }\end{array}$ \\
\cline { 2 - 4 } & 7 & 7 & 12 \\
\hline $\begin{array}{l}\text { Choosing a better } \\
\text { simulation }\end{array}$ & 4 & 4 & 10 \\
\hline
\end{tabular}

The level of satisfaction with the simulation was compared with the number of points obtained from the test. The $\chi^{2}$ test showed that the simulation assessment did not affect the result obtained in the whole test $\left(\chi^{2}=0.376, d f=2, p=.829\right)$.

\section{Discussion}

The lack of statistically significant differences in the post-test results of children of the "University of Children and Parents run by the Pedagogical University" in Krakow and children of the "Children's University run by the House of Culture in Wadowice" shows that the use of proposed simulations for children aged 8-12 is possible regardless of the cultural environment, from which children come from. Therefore, these simulations can be used in any primary school.

The results obtained by participated children (see Figures 4 and 5) showed a relatively high level of correct answers - the average score in the post-test for the children working on the 'sandwich simulation' was $71 \%$, for the 'balancing of the reaction' to $57 \%$. Considering that it was a completely new subject for children with whom they had never met before (answers from 
Martin BÍLEK, Małgorzata NODZYŃSKA, Wioleta KOPEK-PUTAŁA, Paulina ZIMAK-PIEKARCZYK. Balancing chemical equations using sandwich making computer simulation games as a supporting teaching method

OF EDUCATION

IN THE $21^{\text {st }}$ CENTURY

Vol. 76, No. 6, 2018

a pre-test) and a very short time of classes (30 minutes), it seems that the obtained results are satisfactory. Therefore, it can be stated that the children understood what is involved in the reconciliation of the number of elements on the left and right sides. That is why the proposed activities can be carried out on a typical lesson at school (45 minutes) even by a teacher who does not know chemistry, e.g. maths teacher (during the experiment, the children worked individually with the work cards).

It also seems that a much lower percentage of correct answers was to the last 3 questions regarding 'balancing chemical equations':

- How many and what 'Leftovers' will be left to you? water [...],

- hydrogen [...],

- oxygen [...].

It results from the much greater difficulty of this question compared to the other questions. All questions about sandwiches and the first two questions about chemical reaction equations only concerned the amount of 'Reagents' and 'Products' (the number of 'Leftovers' was equal to 0 ). In question 4 it was different. Detailed analysis showed that children, who did not answer this question correctly, left this field blank. This is probably due to their confusion. In this reaction equation water is a 'Product' and not a 'Leftover'. Without knowing what to write they left the answer to this question empty. This interpretation seems to be correct, because in answering the question 3 also regarding the number of water molecules in this equation - only formulated differently (If you use 3 molecules of hydrogen $\left(H_{2}\right)$ and 2 molecules of oxygen $\left(\mathrm{O}_{2}\right)$ - how many molecules of water $\left(\mathrm{H}_{2} \mathrm{O}\right)$ will be formed [...]?) in most cases they answered correctly $(69.2 \%)$. It can therefore be considered that this type of question is too difficult for children of this age.

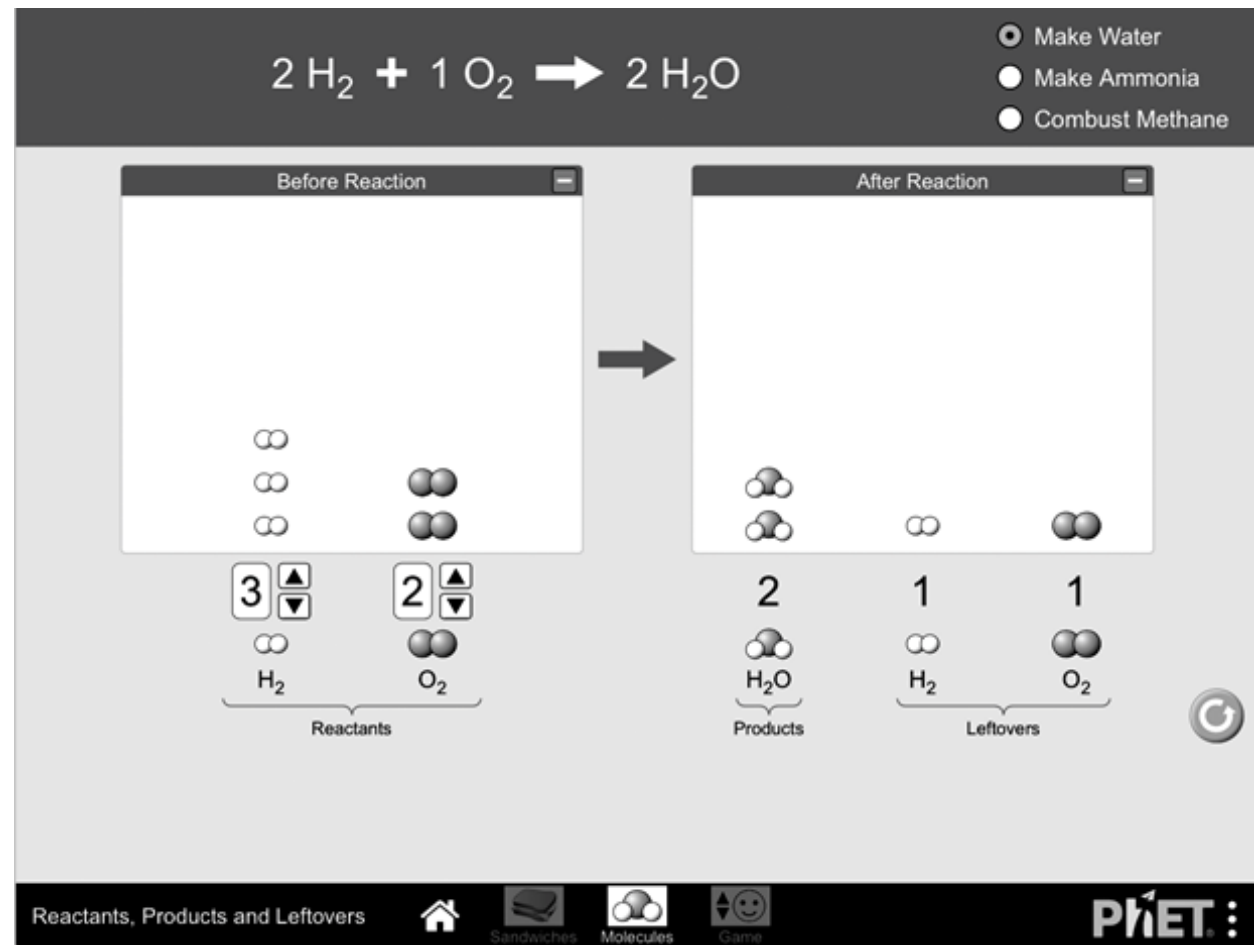

Figure 6. Simulation screen showing problems related to question IV.

(If you use 3 molecules of hydrogen $\left(\mathrm{H}_{2}\right)$ and 2 molecules of oxygen $\left(\mathrm{O}_{2}\right)$ - how many molecules of water $\left(\mathrm{H}_{2} \mathrm{O}\right)$ will be formed [...]? How many and what 'Leftovers' will be left to you? water [...], hydrogen [...], oxygen [...].) In the analysis of results - answers 4-6 correspond to him. 
From the above considerations, it appears that at the level of primary school, the tasks in which 'Leftovers' remain. You also can not ask questions that confuse children.

Considering the better results for 'making sandwiches' (Figure 4 in Appendix), it is recommended to translate children' balancing of chemical reactions started from their closer everyday phenomenon (making sandwiches) to go to a more abstract one (matching the number of molecules in the reaction equations).

Because the research showed that the obtained results are not affected by the student's preference for simulation or the assessment of classes by the respondents - it seems that regardless of the children' interests, this simulation can be used and bring positive results. The obtained results showed a positive example of using the PhET simulation in a similar way as in the previously quoted studies (Carpenter, Moore, \& Perkins, 2016a; 2016b; Clark \& Chamberlain, 2014; Ganasen \& Shamuganathan, 2017; Lancaster, Moore, Parson, \& Perkins, 2013; Moore, Chamberlain, Parson, \& Perkins, 2014; Padilla, Lynch, Diallo, Gore, Barraco, Kavak, \& Jenkins, 2016).

\section{Conclusions}

The conducted research confirmed the main hypothesis and showed that the use of computer simulation allowed children aged 8-12 to understand the ideas of balancing chemical equations. Therefore, the process of teaching writing and balancing equations of chemical reactions can be divided into several stages. In the first stage children were familiarized only with the mathematical and combinational side of this process (using simulations that further visualize this process). This stage can take place in math or nature lessons, children do not have to be familiar with chemistry. The next step is to familiarize children with chemical formulas and principles regarding chemical changes (formation of new substances). Only at the end, children combined these skills - by writing and balancing equations of chemical reactions.

The spread of learning 'writing and balancing chemical equations of reactions' for a few years allowed children to better assimilate this activity. In chemistry classes, children writing equations of chemical reactions don't think about the mathematical side of the process, they only focus on chemical knowledge (transformation of one substance into another).

Because the studies have shown the effectiveness of the use of this simulation regardless of the social and educational environment of children and regardless of their interest in the subject - this simulation can be used in any primary school.

Research has shown that for children it is easier to "make sandwiches" than "balancing chemical reactions", so when working with this simulation, it is better to start with the activity known to children in everyday life "making sandwiches". Obtained results have shown that it is possible to teach children how to balance equations of chemical reactions (without a chemical context). This allows the introduction of balancing chemical reactions at lower levels of education (e.g. on math lessons). In further chemical education, these children will have fewer problems with balancing chemical reactions. Further research should concern subsequent stages balancing chemical reactions.

\section{Acknowledgements}

This research was supported by program PROGRES Q17, part 5 "Teachers Education and Teacher's Profession in Science and Research Context" at Faculty of Education Charles University (Czech Republic) and research project No. BS-463/G/2018 at Pedagogical University in Cracow (Poland) and specific research project No. 2108/2018 at Faculty of Science University of Hradec Kralove (Czech Republic). 
Martin BÍLEK, Małgorzata NODZYŃSKA, Wioleta KOPEK-PUTAŁA, Paulina ZIMAK-PIEKARCZYK. Balancing chemical equations using sandwich making computer simulation games as a supporting teaching method

\section{PROBLEMS \\ OF EDUCATION \\ IN THE $21^{\text {st }}$ CENTURY \\ Vol. 76, No. 6,2018 \\ 792 \\ References}

Agarwal, D. D. (2004). Modern methods of teaching chemistry. New Delhi: Sarup Sons, p. 196.

Belford, R., \& Moore, E. B. (2016). ConfChem conference on interactive visualizations for chemistry teaching and learning: An introduction. Journal of Chemical Education, 93 (6), 1140-1141.

Agaciak, A. (2010). Kraków wbrew statystykom ma milion mieszkańców [In spite of statistics, Kraków has a million inhabitants]. Retrieved from http://krakow.naszemiasto.pl/.

Ben-Zvi, R., Eylon, B. S., \& Silberstein, J. (1987). Students' visualization of a chemical reaction: Research work pinpoints student difficulties in understanding chemical reactions. Education in Chemistry, 24, 117-120.

Bergquist, W., \& Heikkinen, H. (1990) Student ideas regarding chemical equilibrium: What written test answers do not reveal. Journal of Chemical Education, 67 (12), 1000.

Bílek, M., Cieśla, P., Nodzyńska, M., Paśko, I., \& Paśko, J. R. (2006a). Badanie umiejętności tworzenia modeli strukturalnych substancji o budowie jonowej przez uczniów wyższych klas szkół podstawowych [Research of the ability to create structural models of substances of ionic structure by students of the upper classes of primary schools]. In K. Myška, \& P. Opatrný, (Eds.), Soudobé trendy v chemickém vzděláváni: (Aktuální otázky výuky chemie XVI.) Sborník přednášek. [Contemporary trends in chemical education. Current Issues of Teaching Chemistry XVI. Proceedings of Lectures] (pp. 146-153). Hradec Králové: Gaudeamus.

Bílek, M., Cieśla, P., Nodzyńska, M., Paśko, I., \& Paśko, J. R. (2006b). The influence of computer animated models on pupils' understanding of natural phenomena in the micro-world level. In J. R. Paśko \& M. Nodzyńska (Eds.) Badania w dydaktyce przedmiotów przyrodniczych [Research in didactics of natural sciences] (pp. 55-57). Kraków: Jaxa.

Carpenter, Y., Moore, E. B., \& Perkins, K. K. (2016). ConfChem conference on interactive visualizations for chemistry teaching and learning: Using an interactive simulation to support development of expert practices for balancing chemical equations. Journal of Chemical Education, 93 (6), 11501151.

Ceyhun, I., \& Karagolge, Z. (2009). Using algebraic and matrix method for balancing chemical equations energy education science and technology, Part B. Social and Educational Studies, 1 (3-4), 127137.

Chandrasegaran, A. L., Treagust, D. F., Waldrip, B. G., \& Chandrasegaran, A. (2009). Students' dilemmas in reaction stoichiometry problem solving: Deducing the limiting reagent in chemical reactions. Chemistry Education Research and Practice, 10 (1), 14-23.

Chang, H.-Y., Quintana, C., \& Krajcik, J. S. (2010). The impact of designing and evaluating molecular animations on how well middle school students understand the particulate nature of matter. Science Education, 94, 73-94.

Cieśla, P., \& Paśko, J. R. (2006). Dlaczego pisanie równań reakcji chemicznych, w których powstają sole przysparza uczniom wiele kłopotów? [Why writing equations of chemical reactions in which salts arise causes students many problems?]. In K. Myška \& P. Opatrný (Eds.) Soudobé trendy $v$ chemickém vzdělávání: (Aktuální otázky výuky chemie XVI.): Mezinárodní seminár̆: sbornik přednášek, [Contemporary Trends in Chemical Education: (Current Issues of Teaching Chemistry XVI.): International Seminar: Lecture Collection] (pp.42-46). Hradec Králové: Gaudeamus.

Clark, Ch. (2014). Use of a PhET interactive simulation in general chemistry laboratory: models of the hydrogen atom. Journal of Chemical Education, 91 (8), 1198-1202.

Cokadar, H. (2013). Undergraduates' conceptions about balancing chemical equations, and chemical reaction classification. Hacettepe Universitesi Egitim Fakultesi Dergisi - Hacettepe University Journal of Education, 28 (3), 111-122.

Ganasen, S., \& Shamuganathan, S. (2017). The effectiveness of physics education technology (phet) interactive simulations in enhancing matriculation students' understanding of chemical equilibrium and remediating their misconceptions. In M. Karpudewan, A. N. MdZain, \& A. L. Chandrasegaran, (Eds.) Overcoming Students' Misconceptions in Science. Strategies and Perspectives from Malaysia (pp.157-178). Singapore: Springer Nature.

Garnett, P., Hackling, M., \& Oliver, R. (1996). Development of an interactive multimedia package designed to improve students' understanding of chemical equations. In M. W. Hackling, (Ed.) Proceedings of the $21^{\text {st }}$ Annual Conference of the Western Australian Science Education (pp. 6571). Perth: University of Perth. 
Garcia-Martinez, J., Serrano-Torregrosa, E., \& Atkins, P. W. (Eds.) (2015). Chemistry education: Best practices, opportunities and trends. Weinheim: Wiley-VCH.

Główny Urząd Statystyczny (2014). Powierzchnia i ludność w przekroju terytorialnym w 2014 [Area and population in territorial cross-section in 2014] Retrieved from http://stat.gov.pl/obszarytematyczne/ludnosc/ludnosc/powierzchnia-i-ludnosc-w-przekroju-terytorialnym-w-2014-r,7,11. html.

Haduch, I., \& Paśko, J. R. (1999). Trudności w uzgadnianiu współczynników równań reakcji chemicznych wśród uczniów szkół podstawowych [Difficulties in balancing the coefficients of chemical reaction equations among primary school students]. In XI Szkoła Problemów Dydaktyki Chemii VII Konferencja Dydaktyków Chemii - Polska Chemia w Unii Europejskiej [XI School of Didactics of Chemistry, VII Conference of Chemistry Didactics - Polish Chemistry in the European Union] (pp. 308-309). Poznań: UAM.

Healy, A. F., \& Wohldmann, E. L. (2012). Specificity and transfer of learning. In B. H. Ross (Ed.) Psychology of learning and motivation (pp. 227-253). San Diego: Elsevier Academic Press.

Hsin-Yi Chang, Zhihui, H., Zhang, \& Shu-Yuan Chang (2014). Adaptation of an inquiry visualization curriculum and its impact on chemistry learning. The Asia-Pacific Education Researcher, 23 (3), 605-619.

Hsin-Yi, Ch., \& Shi-Fang, T. (2017). Investigating Taiwanese students' visualization competence of matter at the particulate level. International Journal of Science and Mathematics Education, 7, 333.

Jones L. L., \& Kelly R. M. (2015). Visualization: The key to understanding chemistry concepts. ACS Symposium Series, 1208, 121-140.

Kern, A. L., Wood, N. B., Roehrig, G. H., \& Nyachwaya, J. (2010). A qualitative report of the ways high school chemistry students attempt to represent a chemical reaction at the atomic/molecular level. Chemistry Education Research and Practice, 11 (3), 165-172.

Lamanauskas, V. (2011). Digital education: Some implications. Journal of Baltic Science Education, 10 (4), 216-218.

Lancaster, K., Moore, E. B., Parson, R., \& Perkins, K. K. (2013). Insights from using PhET's design principles for interactive chemistry simulations. ACS Symposium Series, 1142, 97-126.

Marais, F. (2014). Improving teaching chemistry: learning from the different ways in which students describe chemical behaviour. In L. G. Chova, A. L. Martinez, \& I. C. Torres (Eds.), ICERI 2014 Proceedings $7^{\text {th }}$ International Conference of Education, Research and Innovation (pp. 59175920). Valencia: IATED.

Moore, E. B. (2016). ConfChem conference on interactive visualizations for chemistry teaching and learning: Accessibility for PhET interactive simulations - progress, challenges, and potential. Journal of Chemical Education, 93 (6), 1160-1161.

Moore, E. B., Chamberlain, J. M., Parson, R., \& Perkins, K. K. (2014). PhET Interactive Simulations: Transformative Tools for Teaching Chemistry. Journal of Chemical Education, 91 (8), 1191-1197.

Moskal, K., \& Nodzyńska, M. (2015). The impact of e-learning on the interest in nature among students of the University of Children and Parents at the Pedagogical University of Krakow. In M. Nodzyńska, P. Cieśla, \& K. Różowicz, (Eds.), New technologies in science education (pp. 66-79). Krakow: Pedagogical University.

Naah, B. M., \& Sanger, M. J. (2012). Student misconceptions in writing balanced equations for dissolving ionic compounds in water. Chemistry Education Research and Practice, 13 (3), 186-194.

Nodzyńska, M., \& Paśko, J. R. (2008). Badania stopnia trudności wykonywanych operacji umysłowych na przykładzie równań reakcji otrzymywania soli. [Examination of the degree of difficulty of mental operations performed on the example of salt reaction equations.] In K. Nesmerak, (Ed.), Current Trends in Chemical Curricula: Proceedings of the International Conference (pp. 67-72). Prague: Charles University, Faculty of Science.

Nodzyńska, M., \& Paśko, J. R. (2010). Automonitorowanie (przez uczniów) czynności umysłowych niezbędnych do uzgodnienia równania reakcji [Self-monitoring (by students) of the mental activities necessary to balance chemical equation]. Chemické Rozhl'ady, 5, 115-122.

Nyachwaya, J. M., Warfa, A. M., Roehrig, G. H., \& Schneider, J. L. (2014). College chemistry students' use of memorized algorithms in chemical reactions. Chemistry Education Research and Practice, 15 (1), 81-93. 
Martin BÍLEK, Małgorzata NODZYŃSKA, Wioleta KOPEK-PUTAŁA, Paulina ZIMAK-PIEKARCZYK. Balancing chemical equations using sandwich making computer simulation games as a supporting teaching method

\section{PROBLEMS \\ OF EDUCATION \\ IN THE $21^{\text {st }}$ CENTURY Vol. 76, No. 6, 2018 \\ 794}

Padilla, J. J., Lynch, Ch. J., Diallo, S. Y., Gore, R. J., Barraco, A., Kavak, H., \& Jenkins, B. (2016). Using simulation games for teaching and learning discrete-event simulation. In Winter Simulation Conference - Winter Simulation Conference Proceedings (pp. 3375-3384). Washington: INFORMS.

Ramirez del Carmen, D., \& Macias, M. E. (2013). Solving material balance problems at unsteady state using a remote laboratory in the classroom. In ASEE Annual Conference Book Series: ASEE Annual Conference, Washington: ASEE.

Paśko J. R., \& Jyż-Kuroś D. (2008a). CHEM TUTOR application as didactic measure increasing chemical education process quality. In M. Nodzyńska \& J. R. Paśko (Eds.) Badania w dydaktyce przedmiotów przyrodniczych: monografia [Research in Didactics of the Science: monograph] (pp. 177-181). Kraków: Uniwersytet Pedagogiczny.

Paśko J. R., \& Jyż-Kuroś D. (2008b). Program ChemTutor jako źródło informacji o sposobie uczenia się i czasie poświęconym na opanowanie danego zagadnienia przez uczniów. [The ChemTutor program as a source of information about the way of learning and time devoted to learning the problem by students] In J. Morbitzer (Ed.) Komputer w edukacji: 18. ogólnopolskie sympozjum naukowe, Kraków 26-27 września 2008 [Computer in education: $18^{\text {th }}$ Polish scientific symposium, Krakow, 26-27 September 2008] (pp. 172-175). Krakow: Pracownia Technologii Nauczania AP.

Rius-Alonso, C. A., \& Gonzalez Quesada, Y. (2015). Teaching chemistry to 2-3 years old children. In L. G. Chova, A. L. Martinez, \& I. C. Torres, (Eds.) Proceedings. $8^{\text {th }}$ International Conference of Education, Research and Innovation (pp. 7441-7448). Sevilla: ICERI,

Rosenthal, D. P., \& Sanger, M. J. (2012). Student misinterpretations and misconceptions based on their explanations of two computer animations of varying complexity depicting the same oxidationreduction reaction. Chemistry Education Research and Practice, 13 (4), 471-483.

Rosenthal, D. P., \& Sanger, M. J. (2013). How does the order of viewing two computer animations of the same oxidation-reduction reaction affect students' particulate-level explanations? In J. P Suits, \& M. J. Sanger (Eds.) Symposium on animations and simulations: What are their pedagogic roles? ACS Symposium Series, 1142, 313-340.

Salaken, S. M., Khosravi, A., Nguyen, T., \& Nahavandi, S. (2019). Seeded transfer learning for regression problems with deep learning. Expert Systems with Applications, 115, 565-577.

Sarabando, C., Cravino, J. P., \& Soares, A. A. (2016). Improving student understanding of the concepts of weight and mass with a computer simulation. Journal of Baltic Science Education, 15 (1), 109126.

Schunk, D. H. (2004). Learning theories: An educational perspective. Upper Saddle River, New York: Pearson, p. 220.

Schurmeier, K. D., Shepler, C. G., Lautenschlager, G. J., \& Atwood, Ch. H. (2011) Using item response theory to identify and address difficult topics in general chemistry. In D. M Bunce (Ed.) Investigating Classroom Myths through Research on Teaching and Learning. ACS Symposium Series, 1074, 137-176.

Thorndike, E. L., \& Woodworth, R. S. (1901). The influence of improvement in one mental function upon the efficiency of other functions. Psychological Review, 8 (3), 247-261.

Urząd Miejski w Wadowicach (n.d.) Rejestr mieszkańców gminy Wadowice, [Register of residents of the Wadowice commune] Retrieved from http://wadowice.pl.

World Health Organization (2011). ‘ Standards and operational guidance for ethics review of healthrelated research with human participants. Geneva: World Health Organization. Retrieved from http://apps.who.int/iris/bitstream/handle/10665/44783/9789241502948_eng.pdf;jsessionid=1E83 6613C008D41618EB4E450A6AA174?sequence $=1$.

\section{Appendix}

\section{Instruction}

The students worked independently, each on their own computer, according to instructions provided to them. The teacher was helpful when the students needed help. 
Martin BÍLEK, Małgorzata NODZYŃSKA, Wioleta KOPEK-PUTAŁA, Paulina ZIMAK-PIEKARCZYK. Balancing chemical equations using sandwich making computer simulation games as a supporting teaching method

The manual contained 3 parts:

1. introduction to the subject,

2. learning to "make sandwiches",

3. learning to balance the equations of chemical reactions on the models.

Part 1 - introduction to the subject

The students did not know the term "chemical reaction" before. This concept was explained by referring to the already known reactions from everyday life (see Figure 1 in Appendix).

There are various chemical reactions around us. You know them from everyday life, such as burning gas in the oven, pickling cucumbers, baking a cake. In order for these reactions to take place correctly, so that the dinner will be cooked and the pot will not be sooty, pickled cucumbers were tasty and the dough did not have a sad cake. The proportions (quantities) in which we add the individual ingredients are important.

To learn how to chemically save these proportions, we will first learn to "make sandwiches".

\section{Figure 1. The beginning of instructions for students - the introduction of the term "chemical reaction".}

Part 2 - learning to "make sandwiches"

The second part of the manual referred to the students' daily skills of making sandwiches and, step by step, described how to make different sandwiches with given parameters using the simulation (Figure 2 in Appendix). Three such activities are described (Figure 3 in Appendix). 
Martin BÍLEK, Małgorzata NODZYŃSKA, Wioleta KOPEK-PUTAŁA, Paulina ZIMAK-PIEKARCZYK. Balancing chemical equations using sandwich making computer simulation games as a supporting teaching method

OF EDUCATION

IN THE $21^{\text {st }}$ CENTURY

Vol. 76, No. 6, 2018

Part 2

Let's make a sandwich with only 2 pieces of bread and 1 slice of cheese:

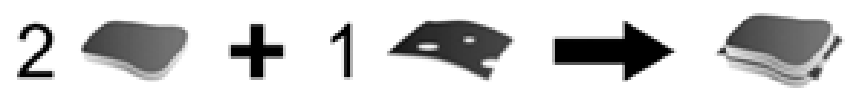

If in the field "Reagents" we choose 2 pieces of bread and 1 slice of cheese we will get 1 sandwich:

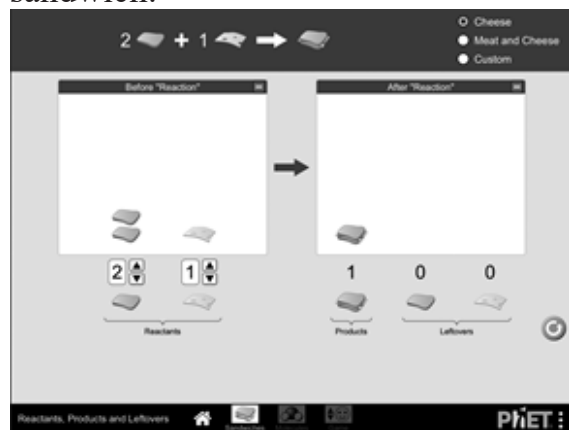

However, if we take, for example, 3 pieces of bread and 2 pieces of cheese, then we will still have only one sandwich, but we will have "Remnants" - an extra 1 slice of bread and an additional 1 slice of cheese.

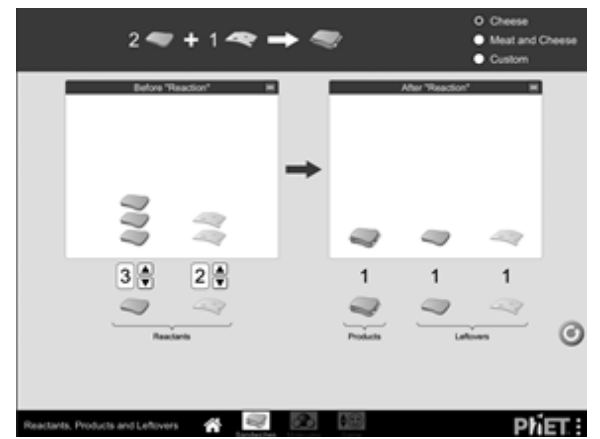

If we add 1 slice of bread, we will get 2 sandwiches:

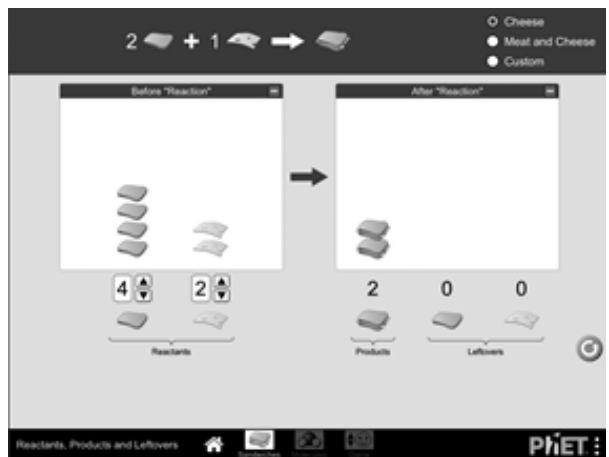

Figure 2. The instructions for students - part 2 - learning to "make sandwiches". 
PROBLEMS

OF EDUCATION

IN THE $21^{\text {st }}$ CENTURY

Vol. 76, No. 6, 2018

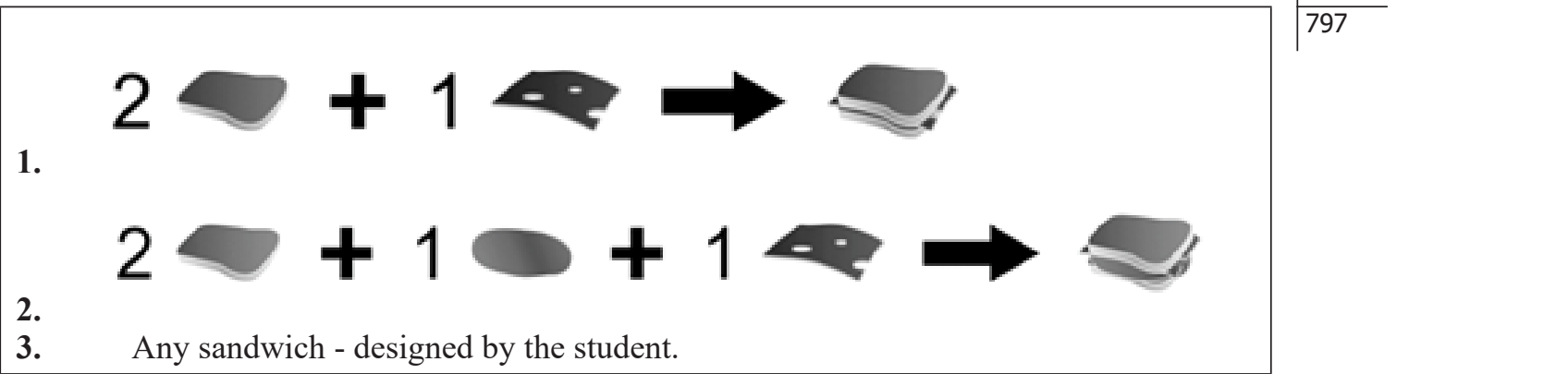

Figure 3. The instructions for students - part 2 - three tasks for students.

Part 3 - learning to balance the equations of chemical reactions on the models

Part 3 of the instructions described, in an analogous manner, three chemical reactions:

- $\quad$ synthesis of the water molecule,

- synthesis of the ammonia molecule,

- and burning methane.

In the case of each of these chemical reactions, the students were tasked with performing 3 simulations according to a detailed instruction (compare Figure 4 in Appendix). 
Martin BÍLEK, Małgorzata NODZYŃSKA, Wioleta KOPEK-PUTAŁA, Paulina ZIMAK-PIEKARCZYK. Balancing chemical equations using sandwich making computer simulation games as a supporting teaching method

OF EDUCATION

IN THE $21^{\text {st }}$ CENTURY

Vol. 76, No. 6, 2018

\section{Part 3}

First, let's build a water molecule:

The model of the water molecule looks as follows:

The red circle is oxygen and white hydrogen

- this means that 1 molecule of water consists of 1 oxygen atom and 2 hydrogen atoms, just like our first sandwich ( 2 pieces of bread and 1 piece of cheese):

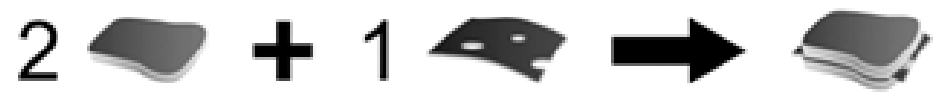

However, oxygen and hydrogen do not exist as single atoms (free ball) - they can only be observed when they are combined into molecules of 2 atoms:

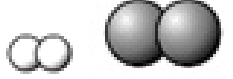

1 hydrogen molecule is composed of 2 hydrogen atoms; 1 the oxygen molecule is composed of 2 oxygen atoms

At the top of the screen we have a "recipe" to receive a water molecule,

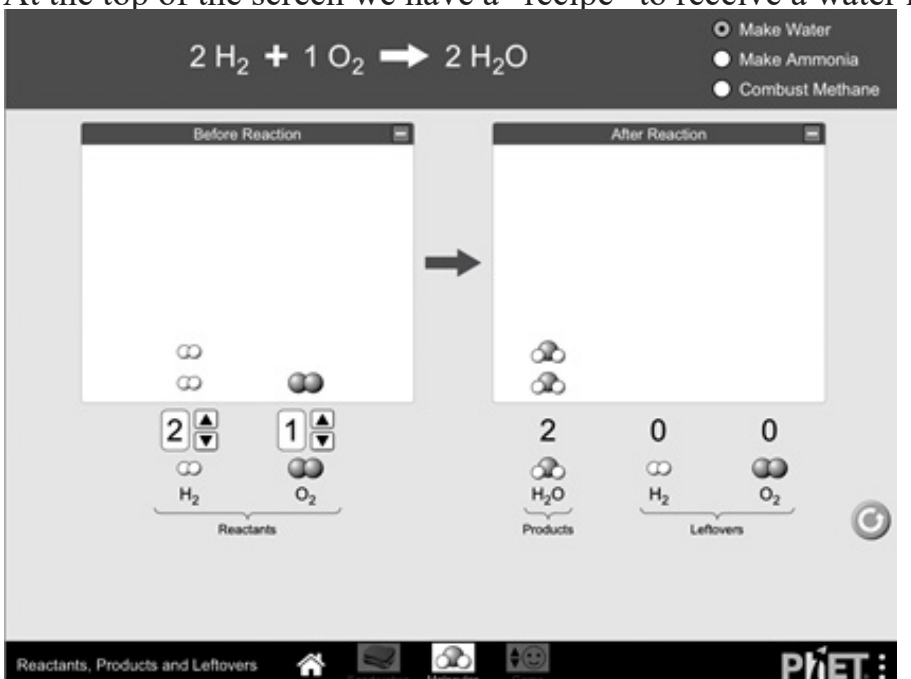

at the bottom is explained using models (balls) how to understand this record: from 2 molecules of hydrogen $\left(2 \mathrm{H}_{2}\right)$ and one molecule of oxygen $\left(1 \mathrm{O}_{2}\right), 2$ molecules of water $\left(2 \mathrm{H}_{2} \mathrm{O}\right)$ are formed:

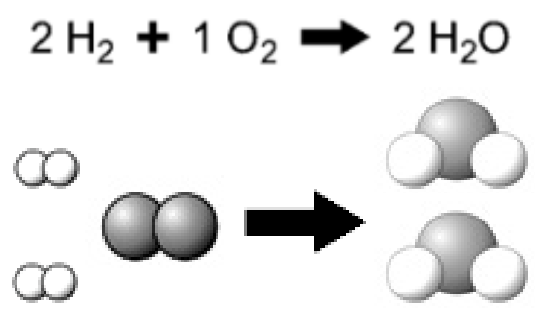

Figure 4. The instructions for students - part 3 - description of the formation of a water molecule. 
Martin BÍLEK, Małgorzata NODZYŃSKA, Wioleta KOPEK-PUTAŁA, Paulina ZIMAK-PIEKARCZYK. Balancing chemical equations using sandwich making computer simulation games as a supporting teaching method

PROBLEMS

OF EDUCATION

IN THE $21^{\text {st }}$ CENTURY

Vol. 76, No. 6, 2018

799

Received: July 07, 2018

Accepted: November 17, 2018

Martin Bílek

Ph.D., Professor, Department of Chemistry and Chemical Education, Faculty of Education, Charles University, M. D. Rettigove 4, Prague, 116 39, Czech Republic.

E-mail: martin.bilek@pedf.cuni.cz

Website: http://www.cuni.cz

Malgorzata Nodzyńska Ph.D., Associate Professor, Department of Didactics of Natural Sciences, Faculty of Geography and Biology, Pedagogical University, Podchorazych 2 , 30 084, Krakow, Poland

E-mail: malgorzata.nodzynska@gmail.com Website: http://www.up.krakow.pl/

Wioleta Kopek-Putala

Ph.D. Student, Faculty of Science, University of Hradec Kralove, Rokitanskeho 62, 500 03, Hradec Kralove, Czech Republic.

E-mail: wioleta.kopekputala@uhk.cz

Website: http://www.uhk.cz

Paulina Zimak-Piekarczyk

Ph.D. Student and Secondary School Teacher, Institute of Plant Physiology, Polish Academy of Sciences, Krakow and State High School of Art, Zakopane, Poland.

E-mail: p.zimak@ifr-pan.edu.pl 